\title{
THE SHAPE OF THE NEW ZEALAND ECONOMY
}

$\underline{I}+1980$

by

B. P. Philpott and B. J. Ross

Paper presented to the New Zealand

Association of Economists

August 1968

Agricultural Economics Research Unit Discussion Paper No. 5

Lincoln College, University of Canterbury, N.Z.

August 1968 


C O N T E N T S

I. INTRODUCTION

II. PROJECTION METHODS AND MODELS

III. GENERAL ASSUMPTIONS

IV. EXPORT ASSUMPTIONS

V. THE SECTORAL PROJECTION MODEL

VI. THE SHAPE OF THE ECONOMY IN 1978/79

VII. ALTERNATIVE ASSUMPTIONS

VIII. THE BEST SHAPE 
This paper was written for presentation at the 1968 Residential Conference of the New Zealand Association of Economists, as the first in a series for which the general theme was "New Zealand in 1980".

It represents some interim results from a continuing programme of research in the Agricultural Economics Research Unit on the structural development of the New Zealand economy.

There is much more work yet to be done in this programme 1 and for this reason the reader is asked to regard as very provisional the results presented. They are not offered as definitive projections of the economy in 1980 but rather as guidelines to assist the conference in discussing its theme.

A number of Lincoln colleagues have assisted us in this work - we would specifically like to acknowledge the help given by $\mathrm{Dr}$ R.W.M. Johnson, Messrs T.W. Francis, D. McClatchy, D.R. Edwards and Mrs L.D. Woods.

\section{B.P. Phi ilpott \\ B.J.ROSS}

Lincoln College,

13 August 1968

1

For an outline of the whole programme see

B.P. Philpott \& B.J. Ross "Input-Output Models

for Projecting and Planning the Economy", Agricultural Economics Research Unit Publication No. 41 . 
THE SHAPE OF THE NEW ZEEALAND ECONOMY IN

\section{I . INTRODUCTIION}

The purpose of this paper is to present, in broad outline, some projections for around the end of the next decade, of the shape of the New Zealand economy. 1

By "shape of the economy" we mean not only the level of the main macro variables such as consumption investment, Government expenditure, exports, imports, labour force etc., but also the break up of these macro magnitudes as between the various important sectors of the economy and particularly the relative accent on traditional exporting industries based on primary production compared with new import substituting and exporting sectors such as manufacturing and tourism.

The projections of the shape of the economy which we present are of course no more than reflections of assumptions adopted with respect to exogenous variables on the one hand; and of the type of model setting out the relationships between endogenous variables on the other. The projections do not purport to be anything other than the end result of using a specific set of assumptions and a specific model or set of relationships. The major virtue of such an exercise is that it forces us to concentrate our critical attention on these assumptions on this model, and this I hope is what will happen in your discussion of this paper.

1 While the title of the paper refers to the year 1980, many of the figures presented here refer to the year 1978/79. This is the target date for the National Development Conference for which much of the work discussed here was done. We have not thought it worth the effort to recalculate for another year. 
Given the acceptability of the assumptions and the model, the results give some idea of what the economy could look like in 1980 or in the years round about that date.

In the next section we discuss very briefly the type of projection model used and then go on to a discussion of the assumptions used - especially those relating to future traditional export prices which are of critical importance.

A further detailed discussion of the model used is then followed by the projections for 1980. In section VI we give the results from varying the assumptions and we conclude by asking some questions about optimisation rather than projection.

The results we give stem from a long term research programme in the Agricultural Economics Research Unit under the general heading of the "structural Development of the New Zealand Economy". This programme was accelerated for use by the Targets Committee of the National Development Conference and many of the deliberations of that committee have been taken into account in writing the present paper. However, because the research programme has been accelerated for this purpose the results must be regarded as highly provisional at this stage.

1 For a fuller description of this work see B.P. Philpott \& B.J. Ross "Input Output Models for Frojecting and Planning the Economy", Agricultural Economics Research Unit Publication No.41, 1968. 
II . PRQUEECTION METHODS AND MODEISS

The New Zealand Institute of Economic Research has prepared projections for $1978 / 79$ of the main macro variables based on a model incorporating relationships between these broad aggregates.

It is useful to discuss this very briefly here before turning to the Iincoln model because the Institute's results provide a useful check on our own work (and vice versa), especially as the two models approached the question from different and indeed opposite directions, even apart from the fact that one deals with aggregate, while the other deals with sectoral projections.

The method adopted by the Institute amounted essentially to the following steps:

(i) A direct forecast was made of the possible increased volume of exports achievable over the decade. 1

(ii) Given expected net overseas investment and forecasts of the terms of trade, these export volumes were then converted into import volumes.

(iii) Alternative levels of per capita gross national product and consumption expenditure were then explored, given these levels of imports and final target levels chosen such that they were consistent with historical ratios of imports and investment to gross national product.

1 The particular values for this forecast and the other assumptions underlying this and the Lincoln model are given in the next section. 
The operation was conducted as a two stage process up to $1972 / 73$ and thence to $1978 / 79$, these being the two target dates for the Development Conference.

The outcome was a projection of growth in gross national product, over the whole period, of about 4.5 per cent per annum and in consumption per capita of 2 per cent per annum ( $1 \frac{1}{2}$ per cent per annum in the first half of the period and $2 \frac{1}{2}$ per cent in the second).

Thus the essential feature of the Institute model is that exports are exogenous and the consumption and product forecasts follow from the export forecast.

The reverse procedure is adopted in the Lincoln projection model which starts with consumption and government expenditure as exogenous variables - derived in fact from the projections thrown up by the Institute model. The procedure is as follows:

(i) Consumption and government expenditure forecasts for $1978 / 79$ are set for each sector.

(ii) Given these forecasts the model solves for

(a) the level of output required in each sector;

(b) the level of investment required in each sector;

(c) the level of imports required in each sector;

(d) and thus the level of exports required.

(iii) It ensures that there is consistent intersectoral balance in the solution.

(iv) The level of exports required can either be satisfied by assuming the same pattern, or sectoral mix of exports as in the base year, or by putting targets or restrictions on some sectors (the traditional export sectors) and throwing the extra export requirements on to other sectors. The finer detail of the Iincoln model will be dealt with in a later section.

Both the Institute and the Lincoln model adopt the same set of basic assumptions and to these we now turn. 
III. GENERALI ASSUMPTIONONS

First we give a number of general assumptions which are adopted in both models, deferring till later the special assumptions regarding export growth and export prices. The assumptions relate to the period to 1978/79, though in some cases it is desirable to show how this is made up as between the two periods to $1972 / 73$ and $1978 / 79$ respectively.

(i) Population growth : 2.0 per cent per annum

(ii) Labour Force : $\quad 1.9$ per cent per annum

(iii) Net Immigration : 5000 per annum

(iv) Terms of Trade : These are assumed to decline by $5 \%$ by $1972 / 73$ and to remain unchanged thereafter. The decline reflects assumed rise in export prices of 5 per cent and in import prices of 10 per cent, both with respect to $1967 / 68$.

(v) Net overseas borrowing: $\$ 80 \mathrm{~m}$. in $1978 / 79$ compared with $\$ 110 \mathrm{~m}$. in $1966 / 67$.

(vi) Investment to G.N.P. ratjo: 27 per cent in 1978/79 compared with recent average rates of 25 per cent (Investment includes changes in stocks).

(vii) Volume of exports : $5 \frac{3}{4}$ per cent per annum made up of 7 per cent per annum to $1972 / 73$ and $4 \frac{1}{2}$ per cent to $1978 / 79$.

(viii) Value of Exports : Given above volume and assumed export price changes, value of exports would rise about 6.2 per cent per annum over the whole period ( 8 per cent and 4.5 per cent in the two half periods).

(ix) Domestic Price Level: For the purposes of converting magnitudes from real terms to current price levels, a price level for consumption and investment expenditure in $1978 / 79$ of 10 per cent above $1967 / 68$ has been assumed. 


\section{IV . EXPORT ASSUMPTIIONS}

We turn now to the special and very important and very arguable assumptions about exports, especially future export prices.

With the overall 6.2 per cent per annum increase in value of exports, the total export value in 1978/79 would be $\$ 1585 \mathrm{~m}$. compared with $\$ 825 \mathrm{~m}$. in $1967 / 68$, but the break up of these exports as between major sectors must depend on our assumptions as to the growth in volume of traditional exports and the future prices at which these can be sold.

The Targets Committee of the Development Conference has produced a set of provisional export targets for main sectors and these were adopted in the projection model as far as agriculture, forestry, fishing, and manufacturing are concerned. These targets, together with the 1967/68 base figures, are as follows:

\section{Exports of Goods and Services}

\begin{tabular}{|c|c|c|}
\hline & \multicolumn{2}{|c|}{$\$ \mathrm{~m}$} \\
\hline & $1967 / 68$ & $1978 / 79$ \\
\hline Agriculture \& Horticulture & 651 & 1140 \\
\hline Forestry & 35 & 85 \\
\hline Fishing & 9 & 25 \\
\hline $\begin{array}{l}\text { Other Manufacturing (excluding non } \\
\text { Primary Product \& Forestry } \\
\text { Processing) }\end{array}$ & 24 & 120 \\
\hline Other Goods \& Services (Transport, & 106 & 215 \\
\hline & $\begin{array}{r}825 \\
===\end{array}$ & $\begin{array}{l}1585 \\
===\end{array}$ \\
\hline
\end{tabular}

Particular importance attaches to the assumptions used in deriving the agricultural projections in view of their critical importance in the overall total and in the sector break up. 
Basically the agricultural volume projections represent an updating, and in some cases an adjustment, of the targets set by the Agricultural Development Conference (and reviewed from time to time by the Agricultural Production Council) for 1972/73, extended in this case to 1978/79. The long run increase in volume of agricultural exports amounts to about 4.3 per cent per annum. The major amendments result from changed views about export prices reflecting partly the break in wool prices and the effects of devaluation.

Some notes, especially on the prices used, now follow:

Sheep Numbers, Lamb, and Wool Production

The Agricultural Development Conference projections were recalculated using an econometric model explaining past changes in sheep numbers, as determined by wool prices and lamb prices and a time trend. 1 Wool prices assumed were $29.6 \not 1$ b. as given below and the lamb schedule assumed to remain at the $1967 / 68$ level. The sheep number increase resulting amounts to about 3.5 per cent per annum.

\section{Lamb \& Mutton Prices}

A projection model for U.K. lamb prices incorporating price and income elasticities estimated in earlier work, 2 was used to estimate the extra lamb which New Zealand could sell in Britain at present prices and what quantities would therefore need to be sold in U.S.A., Canada and Japan in order to dispose of total exports. It was assumed that these could be sold at around present prices.

1

Details of these equations are given in

"Analysis of Changes in Sheep Numbers and Wool Production in New Zealand", Lincoln College Agricultural Economics Paper 361.

B.P. Philpott and M.T. Matheson "An Analysis of the Retail Demand for Meat in the United Kingdom", Agricultural Economics Research Unit Publication No.23. 
The price assumptions used were:

\begin{tabular}{lcc} 
& \multicolumn{1}{c}{$1978 / 79$} & $1965 \% 66$ \\
Lamb & 340 & s﹎ton \\
Mutton & 187 & 384
\end{tabular}

\section{Wool Prices}

Here we used an econometric model explaining long run trends in crossbred prices as determined by world per capita supplies of crossbred wool, world per capita incomes, world per capita supplies of synthetic fibres, and a time trend. I Assuming a future increase in world per capita crossbred supplies of 2 per cent per annum and per capita synthetic fibre increases of 25 per cent per annum, the price level projected for $1978 / 79$ is around $28 \not k 1 b$.

\section{Beef}

Volume projections are largely in line with Agricultural Production Council projections. Prices projected assume the expanding world market forecast by F.A.O. and are:

$$
\frac{1978 / 79}{\$ \text { ton }} \quad \frac{1965 / 66}{400 . b .}
$$

Because a major proportion of our beef is sold in North America the full benefit of devaluation accrues in the above projected price.

\section{Dairy Prógouce}

This is by far the most difficult of our export products on which to form any sort of view about the future.

1 See B.P. Philpott "Long Run Swings in Wool Prices", Agricultural Economics Research Unit Publication No. 32 (forthcoming). 
For the present we have adopted the A.P.C. production projections and in our price projections have adopted the following assumptions:

(i) The U.K. entry into E.E.C. will occur sometime in the mid $70^{\prime} \mathrm{s}$.

(ii) By this time the E.E.C. will have successfully restrained their increases in milk production and anti-dumping arrangements will have been set up at world level to prevent the erosion of our new markets.

(iii) The Japanese dairy import market will have "taken off" around the early 70 's.

Prices projected were:

Butter

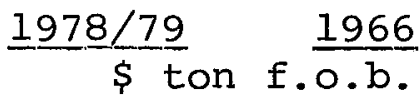

Assuming continuance of U.K. 545 514 quota with non quota butter sold at reduced price

Cheese 440 428

Casein and powders were projected at prices somewhat lower than recent realisations after allowing for devaluation.

These price projections may be regarded by many readers as unduly optimistic (in spite of the fact that except perhaps for wool they largely reflect a continuance of current price levels). Whether or not they are optimistic depends very much, in our view, on the course of events in Japan as a potential importer of New Zealand meat and dairy produce. If all the projections made in this regard come to pass, 1 then we should have no difficulty

1 Including one of the Research Unit's, viz: A.R. Frampton "A Market Target for the New Zealand Dairy Industry", Agricultural Economics Research Unit Publication No. 16. 
in disposing of the projected quantities of agricultural products, high though these may be. It has seemed to us a reasonable assumption that rapid growth in Japanese import demand will be a fact in the early seventies and thenceforth.

Undoubtedly some readers would wish to question the assumption of wool prices projected at $28 \not 1 \mathrm{lb}$. (compared with the $1967 / 68$ season's average of around $23 \not k$ ). We would not wish to retreat from this projected price which is based on results from a large body of applied research work. Certainly the alternative safer assumption that present $(1967 / 68)$ wool prices will continue, seems to us to allow too little for the general and severe cyclic downturn in the world economy and especially in the textile economy from which we are just emerging. However, in order to assuage the pessimists on wool prices, we have produced an alternative set of agricultural export projections based on lower wool prices and also allowing for lower volume of both wool and dairy produce as follows:

Low Agricultural Export Projections

For wool we assume an average price of

$21 \not \subset 1 \mathrm{~b}$. and an export volume growth rate

of 3 per cent per annum until 1972/73 and

no growth thenceforth.

For dairy products we assume the same prices as before but a volume growth rate of 1 per cent per annum until 1972/73 and no growth thenceforth.

For meat we assume same price and volume growth as before.

\section{The Beef Question}

While some allowance has necessarily been made in the foregoing projections for increased beef production, a much more thorough analysis of this question is required which takes into account the massive structural shift which is now occurring in the sheep industry towards beef and also the rapid growth in dairy beef production. 
Work on a linear programming projection model for sheep numbers, beef, and dairy cattle, is being carried out by some of my colleagues in the Research Unit but it had not, at the time of writing, reached the stage where it could be incorporated in the present projections. Provisional results from this work however indicate that at the export price levels we are using (including wool at $28 \not \alpha)$, there will be a much more marked swing away from sheep towards beef production than we have so far allowed for. This change in the agricultural product mix does not however (as far as can be seen at this stage). imply any substantial change in the total value of agricultural exports compared with the value which we are projecting above and we have therefore ignored it at this stage, though we plan to take account of this work when it is completed. $\bar{l}$

\section{THE SECTORAL PROJECTION MODEL}

We deal here with the methodology of the model used to project the shape of the economy. The discussion is a brief summary only - an extended treatment can be found elsewhere. 2

\section{(1) The General_Nature of the Model}

The model, as originally designed, is aimed at providing a picture of the New Zealand economy at some future date with some sustained target growth rate for consumption and government expenditure.

1

On this matter we are grateful for the assistance of our colleagues R.W.M. Johnson and D. McClatchy, who have been working on the supply projection model. 
It is programmed to provide estimates of each sector's output, exports, imports, and investment, required to satisfy the target growth rate, given the set of current and capital input-output coefficients, the set of incremental capital output coefficients and importoutput coefficients. The sector outputs etc., required must also of course satisfy the condition that sufficient capital of the right sort and origin, is being generated to sustain the required sectoral growth rates and that there are sufficient exports forthcoming to finance the imports required given the permissible level of overseas borrowing.

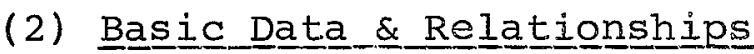

(i) We start with a fifteen sector set of current and capital interindustry accounts and coefficients for 1964/65, representing an updated and condensed version of the Statistics Department's 1959/60 tables. Table 1 in the next section gives the major sector aggregates for $1964 / 65.1$ It should be noted that all valuations in this table are as at factory door or farm gate - the margins from this point to $\mathrm{f} . \mathrm{O} . \mathrm{b}$. in the case of exports are allocated to the particular sectors earning these margins - transport trade etc. For this reason the export figures for each sector and the export projections discussed in the previous sector which are given at $f \circ 0 . b$, values will not agree with those given in the sector tables.

(ii) In using the model for projection we assume that the 1964/65 set of input-output coefficients remain unchanged.

(iii) We also assume unchanged the set of incremental sectoral capital output coefficients which have been calculated for the period 1960-65 relating changes in real gross output in each sector for the period 1960-65 to net investment over the years 1960-64.

For the detailed interindustry tables see

B.J. Ross \& B.P. Philpott "The Interindustry

Structure of the New Zealand Economy 1961-65", Agricultural Economics Research Unit Publication No. 49 (forthcoming). 
(iv) Except in cases where we have investigated the effect of import substitution policies, the importoutput coefficients for each sector have been assumed unchanged at their 1964/65 level.

(v) Labour output coefficients for their inverse labour productivities) have been assumed to change over the period to $1978 / 79$ at the same rate as over the period 1960-65.

(vi) All calculations are carried out (and presented in the projections) in 1964/65 prices except that valuations in $1978 / 79$ prices are also given for exports and imports and the other aggregates have been converted into $1978 / 79$ prices for comparison with the macro projections.

(3) The Working of the Model

(i) The target level of total consumption for $1978 / 79$ (in 1964/65 prices) as thrown up by the macro projections is inserted in the model. This reflects a per capita growth rate in real consumption of 2 per cent per annum over the whole period varying from 1.5 per cent in the first half to 2.5 per cent in the second.

The projected pattern of consumption broken up into the goods and services sold by each of the fifteen sectors and imported, was kindly provided by the N.Z. Institute of Economic Research.

(ii) The projected 1978/79 level of government current expenditure (at $1964 / 65$ prices) was also included, using data broken up into sectors provided by Treasury.

(iii) The procedure with regard to exports varied. While the model was basically designed to throw up the levels of exports required from each sector according to the same sectoral $\mathrm{mix}$ as in 1964/65, for the purposes of this exercise the levels of exports from sectors 1 to 6 were restrained to the target levels discussed in the preceding section 
and the model then determined the extra exports required from other sectors again in the same proportion as in 1964/65.

(iv) Given the target levels of consumption and government expenditure for 1978/79, the model is then solved to give new equilibrium levels of

(a) Total output of each sector.

(b) Exports required from non targeted sectors.

(c) Imports required by each sector.

(d) Sales of consumer and government goods by each sector and direct imports of such goods.

(e) Sales of capital goods by each sector and direct imports of such goods.

(f) Investment required by each sector.

(g) Labour force required by each sector. The solution is secured subject to the condition that:

(h) Total exports equal total imports less planned overseas capital inflow ( $\$ 80 \mathrm{~m}$. in $1978 / 79)$.

(i) The level of gross investment and its allocation between sectors is adequate to maintain the target growth rate in consumption.

(j) All interindustry demands for goods and services are satisfied.

The results then present a picture of the shape of the economy if it were growing at the target rate laid down and to this picture we now turn. 
VI. THE SHAPE OF THE ECONOMY IN 1978/79

The projections which follow were all calculated as a two-stage process incorporating the different target growth rates set for the period up to $1972 / 73$ and thence to $1978 / 79$.

Table 1 which follows gives the picture of the economy in 1964/65 and Table 2 the projection for 1978/79 which emerges from the model as just described, incorporating the assumptions discussed in sections III and IV.

Table 3 gives a comparison for the main aggregates between the results from the sector model and the Institute's macro projections discussed before. Remembering the differences in approach adopted and the highly tentative nature of some of the coefficients in the sector model, the degree of concordance between the two sets of figures is surprisingly satisfactory.

Returning now to the individual sector figures in Table 2, we may note one or two aspects.

(i) Exports required at $\$ 1652 \mathrm{~m}$. are $\$ 70 \mathrm{~m}$. greater than the National Development Conference target suggesting that this latter target is an absolute minimum.

(ii) The projected shape of the economy is happily one with near full employment. Labour requirements total 1210 and projected labour force for 1978/79 is 1240 .

(iii) The labour force in agriculture is subject to an absolute decline compared with 1964/65.

(iv) The investment requirements are 27.2 per cent of gross national product - a fraction above the 27 per cent programmed in the macro model which itself represents a substantial increase in the savings ratio given the restriction on overseas borrowing. 
TABLE 1 LINCOLN MODEL BASE YEAR 1964/65

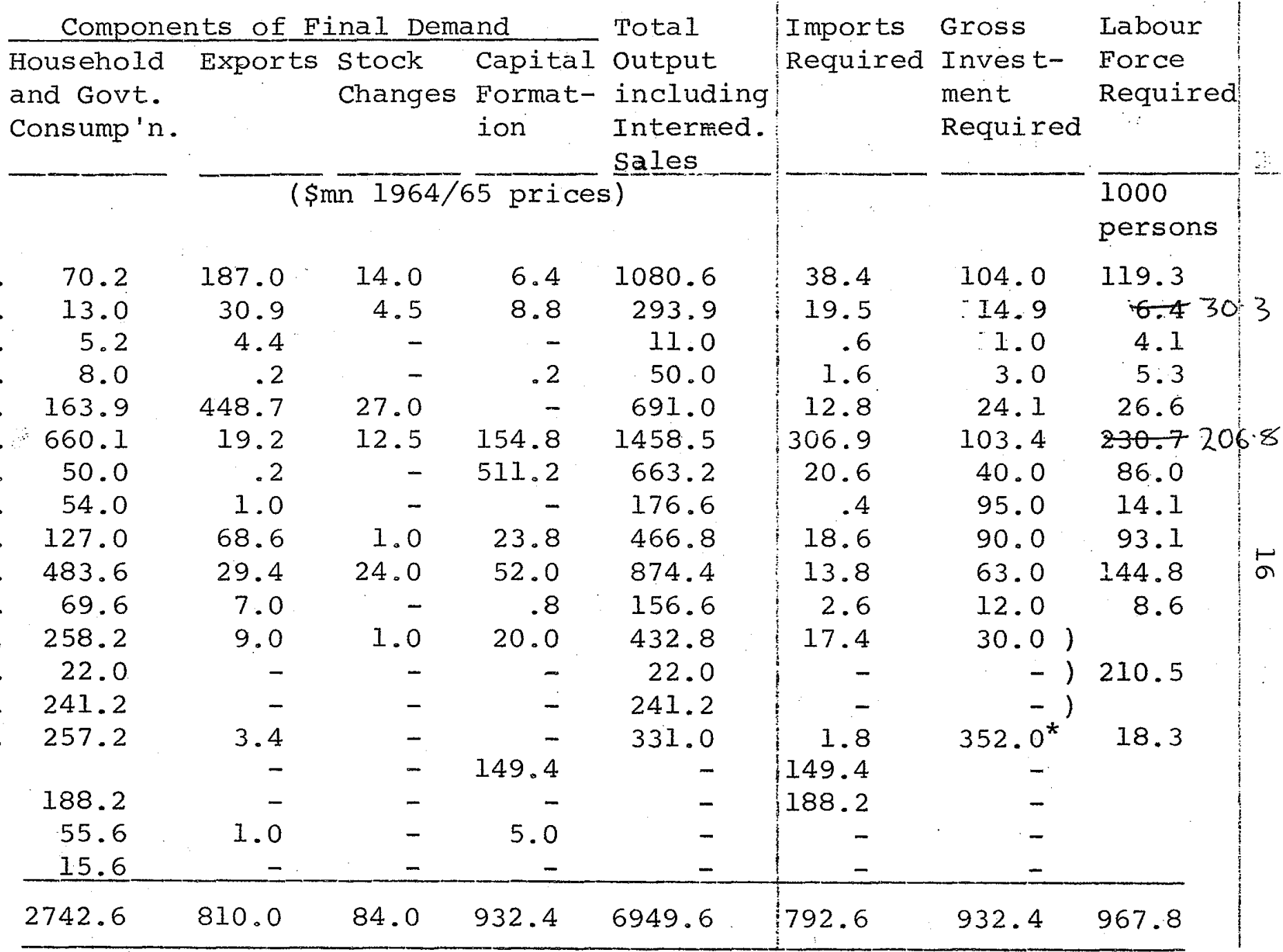

Includes Autonomous Government Investment. 


\section{Sector}

\section{Farming}

Forestry \& Processing 1. Hunting \& Fishing 3 Mining

Prim.Prod.Proc.

other Mfrg.

Building

Public Utilities

\section{Transport}

Trade

Banking \& Ins.

Services

" to Households

" to Government

Property

Imports 1) Capital

$$
\text { - 2) Cons . }
$$

Indirect Tax

other Value Added

Total 1964-65 Prices Total 1978-79 Prices

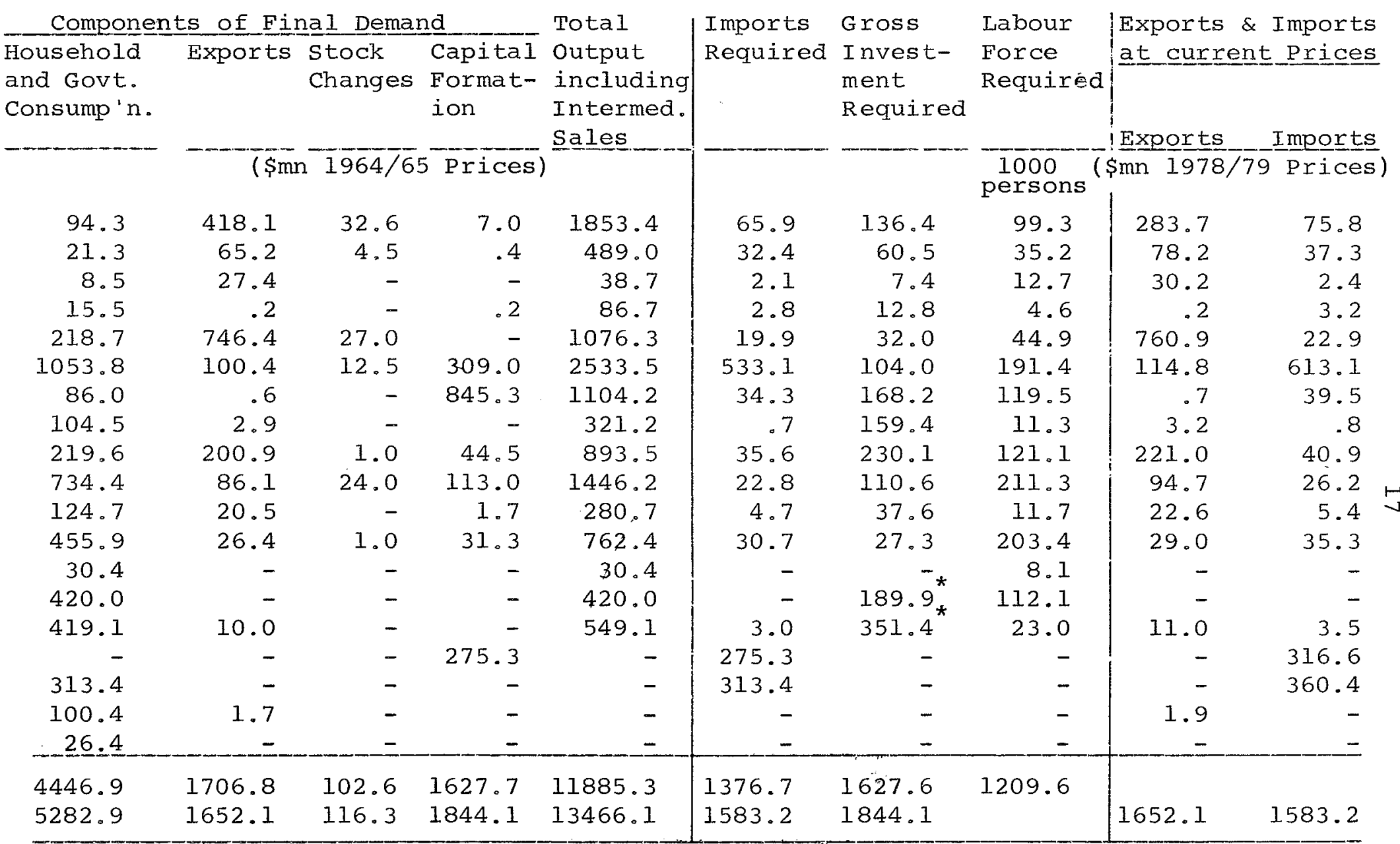

* Includes some Autonomous Investment 
TABLE 3

$\begin{array}{cl}\text { Macro } & \begin{array}{l}\text { Sector } \\ \text { Model }\end{array} \\ \text { Model }\end{array}$

Consumption \& Government Current Expenditure

Investment \& Change in Stocks

$1938 \quad 1960$

Exports of Goods \& Services

1584

1652

Imports of Goods \& Services

1514

1582

Factor Payments Abroad (net)

$120 \quad 120$

Gross National Product

7177

7193

Ratio of:

Investment \& Stocks to G.N.P. \% 27.0

This then represents our view of the shape of the economy in 1980. The statistical picture presented should allow, and indeed stimulate, plenty of argument. However, we do not wish to conclude our exercise at this point. It is useful to explore the effect on the projections of varying some of the assumptions on which we have been operating - in particular to examine the effect of pessimistic assumptions about agricultural prices and volume. This we turn to in the next section. 
VII. ALTERNATIVE ASSUMPTIONS

\section{(1) Low Projections for Agricultural Prices \& Volumes}

In this analysis we assumed that agricultural prices and volumes were at the lower level discussed in the latter part of section IV, and we set these as targets for sectors 1 and 5. Sectors 2-4 were set at N.D.C. target levels and Sectors 7-15 were set as targets at the level which emerged from the projection in the previous section as in Table 2 . The increased exports required on account of the shortfall in agriculture was then all thrown on to sector 6 "Other Manufacturing". The results summarised are:

\begin{tabular}{ccc} 
Exports with High Prices & $\begin{array}{c}\text { Agriculture } \\
\text { Sectors } \\
1 \text { and 5 }\end{array}$ & $\begin{array}{c}\text { Other } \\
\text { Manufacturing } \\
\text { Sector 6 }\end{array}$ \\
Exports with Low Prices & 1045 & 115 \\
Change & -852 & 336 \\
\hline m. & -192 & 221 \\
\hline
\end{tabular}

The important result here is that to compensate for the fall in agricultural exports a further net $\$ 30 \mathrm{~m}$. of manufacturing exports are required - to pay for the imported capital equipment and raw materials required.

The level of manufacturing exports required at $\$ 336 \mathrm{~m}$. (compared with $\$ 20 \mathrm{~m}$. in 1965) must be regarded as very high indeed, even allowing for the recent upsurge in such exports.

\section{(2) High Agricultural Prices but Low Volume}

In this analysis we ask what effect would follow from assuming that the original agricultural (i.e. wool) price projections stand, but that agricultural volume slows down to the rate in (1) above. Similar export target arrangements are set as before, i.e. manufacturing is asked to provide all the extra exports required. This is tantamount to investigating a policy of virtually shutting down on agricultural growth and heading for manufacturing as the key exporter. 
The results are:

\begin{tabular}{ccc}
$\begin{array}{c}\text { Agricultural } \\
\text { Sectors } \\
1 \text { and } 5\end{array}$ & $\begin{array}{c}\text { Other } \\
\text { Manufacturing } \\
\text { Sector } 6\end{array}$ & $\begin{array}{c}\text { Total } \\
\text { all } \\
\text { Sectors }\end{array}$ \\
\hline
\end{tabular}

$\begin{array}{crlcc}\text { (i) Exports with High Volume } & 1045 & 115 & 1652 \\ & - \text { High Prices \$m. } & & 1655 \\ \text { (ii) Exports with Low Volume } & 894 & 268 & 1210 \\ - \text { High Prices \$m. } & & 191.4 & 1196 \\ \text { (iii) Labour Force under (i) } & 144.2 & 199.3 & \\ \text { (iv) Labour Force under (ii) } & 128.9 & & \end{array}$

Again we are faced with a more than doubling of manufacturing exports above the already high targets (at $\$ 115 \mathrm{m.})$ set for 1978/79. But even more significant, in our view, is the effect on the total level of employment which is lower under the "manufacturing policy". The fall in agricultural and primary processing sectors of 15,000 persons is only partially offset by the rise of 8000 in manufacturing but there are further falls of 6000 persons in other sectors heavily interdependent with agriculture, both on current and capital account.

Contrary to popular belief, which has found its expression in so much popular policy, the way to create employment in New Zealand is not to industrialise but to "agriculturalise". The naive view ignores too much the importance of sectoral interdependencies in the economy.

\section{(3) Diminishing Returns in Agriculture}

Capital-output ratios are notoriously difficult to estimate. To allow for the possibility of gross error we reran the analysis with a doubling of the incremental capital output ratio in agriculture. This also has the incidental advantage of allowing for the possibility of diminishing returns to capital in agriculture in the future.

Again, as was to be expected, given the analysis in (2) above, the employment requirements rise and so too does the Investment/G.N.P. ratio to $27.7 \%$, indicating, not 
surprisingly, increased capital requirements. The total export requirement also rises $\$ 20 \mathrm{~m}$. to $\$ 1670 \mathrm{~m}$.

\section{(4) Import_Substitution}

The effect on our projection of an import substitution policy was investigated by reducing all current account import output coeffjcients by 10 per cent and all capital import-output coefficients by 5 per cent. A compensating adjustment in each column of the input-output matrix, was made by increasing each sector's purchases from the manufacturing sector by the amount of import reduction effected. Not surprisingly the level of imports, and therefore exports, fell by about $\$ 115 \mathrm{~m}$. to $\$ 1537 \mathrm{~m}$. compared with $\$ 1652 \mathrm{~m}$. previously. This drop of $\$ 115 \mathrm{~m}$. compares with the direct effect of the 10 and 5 per cent cut in import coefficients which amounted in value terms to $\$ 145 \mathrm{~m}$. $\$ 30 \mathrm{~m}$. was therefore needed to pay for extra imports of raw materials and capital equipment for manufacturing industry. Total investment requirements did not rise significantly. Clearly some degree of import substitution of the correct sort is one way of reducing the export requirements as generated by the sector model to the lower level projected by the macro model which implicitly assumes a degree of structural change of this sort.

\section{(5) The Level of Protection of the Manufacturing Sector}

It was hoped to evaluate the effect of revaluing the output of the manufacturing at world prices (comparable with imports and therefore with the real earning power of exports) but there has not been time to do this. The point must nevertheless be made even if it cannot be quantified.

Due to the effect of tariffs, but more particularly the protective effect of import controls, the value of output of manufacturing industry is inflated and $\$ 100$ of consumer expenditure on domestically produced products does not represent the same real value as $\$ 100$ of comparable imports. This ought to temper our enthusiasm for the import substitution results mentioned above.

But there is a further and possibly more important aspect to be noted in connection with manufactured exports. 
Many of these are at present being sold at much lower prices than in the home market - in some cases based on marginal cost.

To this extent, $\$ 100$ of manufacturing exports is likely to require a greater volume of resources than $\$ 100$ sold domestically. The model of course assumes no difference in coefficients reflecting resources required for manufacturing output sold domestically or exported, so that the real effect on the economy of reaching the manufacturing export targets (let alone the $\$ 267 \mathrm{~m}$. - $\$ 336 \mathrm{~m}$. - high level manufactured exports) will be much greater than we have allowed for. This effect is further compounded if we allow for the real effect of export incentives granted.

Earlier on (in subsection (1)), we showed that to make up for a loss of $\$ 192 \mathrm{~m}$. in agricultural exports, an increase of $\$ 221 \mathrm{~m}$. in manufacturing exports would be required. This result çan and has been generalised for situations which are not confounded (as the above one is) by changes in the terms of trade. With given $(1964 / 65)$ terms of trade we find that:

to achieve a $\$ 100 \mathrm{~m}$. net increase in exports we require either $\$ 122 \mathrm{~m}$. of agricultural exports or $\$ 144 \mathrm{~m}$. of manufacturing exports. after allowing for all reactions throughout the economy, including the increased capital required.

In some sense we can talk of $144: 122$ as being the rate of substitution of manufactured exports for agricultural exports. The import of the above argument concerning costs of protection is to raise the $\$ 144 \mathrm{~m}$. even higher. 
VIII. THEE_BEST $\underline{\text { SHAPE }}$

In addition to giving you our idea as to what is likely to be the shape of the economy in 1980, we have also given you a number of alternative shapes from which you can take your pick. The principle on which one chooses is of course a question of optimisation, on which aspect we conclude.

To choose the optimal shape requires some form of linear or mathematical programming on which we are currently working. Here we can only indicate one or two crude measures which should influence us in making a cut-andthrust approach.

The three important magnitudes for each "shape" seem to us to be
(i)
capital requirements
(ii)
labour requirements
(iii)
manufactured export requirements.

For each of four different programmes we give below these three values ranged in decreasing order of capital requirements.

1. Allowing for Diminishing

\begin{tabular}{|c|c|c|}
\hline Total Marginal & Labour & Manufact- \\
\hline Capital & Requirements & uring Export \\
\hline Requirements & in & Required in \\
\hline $\begin{array}{l}\text { over the 14-yr } \\
\text { Period }\end{array}$ & $1978 / 79$ & $1978 / 79$ \\
\hline$\$ \mathrm{~m}$ & '000 & $\$ \mathrm{~m}$. \\
\hline
\end{tabular}
Returns in Agriculture (Projection VII.3)

2. Basic Projection of

5621

1210 section VI

3. Low Agricultural prices and Volume (Projection VII.1)

4. Low Agricultural Volume - 5290 
The marginal capital requirements given in the above table have been calculated in a special way. They include annual net investment required for each type of policy, cumulated from $1964 / 65$ to $1978 / 79$, plus the replacement of the plant and equipment invested in each of the four years 1965/66 to 1968/69, which, on the assumption of a ten year life, falls due for replacement in each year $1975 / 76$ to $1978 / 79$. In this way some of the enormous difficulties associated with using depreciation allowances as a measure of replacement investment are overcome, 1 and we have at least a crude measure of the capital requirements specific to each programme over the planning period.

on this criterion we should head for programme no. 4 - it has the lowest capital requirements and we could possibly hope to raise the rate of growth and still remain within the broad restriction of a $27 \%$ investment/ G.N.P. ratio.

But it will be noticed as we move down the scale in terms of capital requirements, we also move into positions of lower labour requirements or greater unemployment (recalling that the projected labour force in 1978/79 is $1,240,000$.

Further than this, the exports required from the manufacturing sector at $\$ 267 \mathrm{~m}$ 。 $-\$ 336 \mathrm{~m}$. become absolutely astronomical compared with the $\$ 19 \mathrm{~m}$. in 1964/65 and $\$ 21.5 \mathrm{~m}$. in 1967/68 and this becomes of even greater concern if we recall the adjustment which we consider ought to be made and which we believe would be considerable, for the under-pricing of manufactured exports.

1 only of course to bring new problems - in particular replacement investment in building is not included, as with asset lives of around 40 years it will not fall due until well outside our target horizon. Thus any of the above programmes involving heavy building investment will appear to require less capital in the long run than is really the case. 
Clearly the "optimum" policy can only be derived by setting up the question as a mathematical programming problem and while this is under way we still want to refine a lot of our data and our coefficients before we adopt such refined methods.

In the meantime, and for the purposes of this Conference, we have presented you with a set of alternative "shapes" for you to choose from, but after you have argued it out, as we hope you will, we feel you are likely to come back, as we did, to the picture presented in section VI as being the most likely shape of the economy in 1980 . 